\title{
Species delimitation in the Ponto-Caucasian Viola sieheana complex, based on evidence from allozymes, morphology, ploidy levels, and crossing experiments
}

\author{
Thomas Marcussen • Liv Borgen
}

Received: 16 March 2010/Accepted: 4 October 2010/Published online: 11 November 2010

(C) The Author(s) 2010. This article is published with open access at Springerlink.com

\begin{abstract}
Information from allozymes, ploidy levels, morphology, cross-compatibility and biogeography suggests that the easternmost occurrences of the PontoCaucasian Viola sieheana should be considered to belong to a separate species, V. caspia. Morphological characters delimitating $V$. sieheana and $V$. caspia are presented and discussed. The main distribution of $V$. sieheana $\mathrm{s}$. str. is in the eastern Balkans, Turkey, Cyprus, and The Lebanon, and of $V$. caspia in the Caspio-Caucasian region westwards to Crimea and north-eastern Turkey. Their distributions in the intermediate areas remain unknown. Plants of $V$. sieheana s. str. from Cyprus, Greece, and Turkey were all blue-flowered and had the chromosome number $2 n=12 x=60$. Its presence in the Peloponnese (Parnon, Taÿgetos, Menalon) and in the Pindhos mountains, Greece, was confirmed. Reports of plants with $2 n=8 x=40$ from these stations seem to refer to the sterile hybrid $V$. reichenbachiana $\times$ sieheana which is locally abundant. V. caspia from Azerbaijan had $2 n=8 x=40$ and had either whitish or blue flowers. In spite of sympatry and almost complete cross-compatibility, the two corolla colour morphs showed
\end{abstract}

Electronic supplementary material The online version of this article (doi:10.1007/s00606-010-0377-z) contains supplementary material, which is available to authorized users.

T. Marcussen $(\square)$

University of Oslo, P.O. Box 1045, Blindern, 0316 Oslo, Norway

e-mail: thmsmrcssn@gmail.com

T. Marcussen

Department of Plant and Environmental Sciences,

University of Gothenburg, Gothenburg, Sweden

L. Borgen

National Centre for Biosystematics, Natural History Museum, University of Oslo, P.O. Box 1172, Blindern, 0316 Oslo, Norway strong allozymic differentiation in four out of seven isozyme systems, suggesting reproductive isolation and incipient speciation. Within section Viola, V. caspia and $V$. sieheana seem no more closely related to each other than to either of the other investigated European species. The possibility that $V$. sieheana is an ancient allopolyploid involving the Greek narrow endemic $V$. dirphya $(2 n=40)$ is discussed.

Keywords Allozymes - Cross compatibility ·

Ploidy levels · SE Europe-SW Asia .

Subsection Rostratae · Viola caspia

\section{Introduction}

The caulescent and usually blue-flowered woodland violets form a morphologically and ecologically uniform group with taxa represented in temperate deciduous forests throughout most of the northern hemisphere. The species typically produce chasmogamous, insect-pollinated flowers in spring, and later in the season only cleistogamous flowers. They all belong taxonomically in the palaeotetraploid (Nordal and Jonsell 1998) section Viola subsection Rostratae (Kupffer) W. Becker (=section Trigonocarpea Godr.), which has some 50 species worldwide, but are presumably not monophyletic within this subsection (cf. Harvey 1966; van den Hof et al. 2008). Historically, different woodland species have often been united under the collective species names $V$. canina L., $V$. sylvestris Lam. (=V. canina), and $V$. sylvatica Fr. ex Hartm. (= V. riviniana Rchb.). The confusing taxonomy in this group seems to be due to the modest number of species-delimitating characters, coupled with strong phenotypical plasticity and seasonal variation, cleistogamous inbreeding promoting 
differentiation among populations, and the ability of species to form (mostly sterile) interspecific hybrids. The taxa differ in the details of the chasmogamous flowers (colour and shape of petals and spur, size of calycine appendages), the cauline stipules (size, shape and incision), and to some extent pubescence and shape of the leaves and capsules; in addition, many of the species are allopatric or ecologically separated (Table 1).

In Europe and adjacent temperate North Africa and West Asia, the woodland violets comprise about six species. Three of these, V. reichenbachiana Jord. ex Boreau, $V$. riviniana $\mathrm{Rchb}$. and $V$. sieheana $\mathrm{W}$. Becker, have wide distributions and intertwined nomenclatural histories. The remaining three species are all narrow endemics from southern Europe, $V$. dirphya A. Tiniakou and $V$. oligyrtia A. Tiniakou from Greece, and V. laricicola Marcussen from the Alps. The fact that these endemic taxa have been discovered in recent times (Marcussen 2003b; Tiniakou 1991b, 1995) is in itself an indication of the difficult taxonomy of this group. These species represent three ploidy levels: $V$. laricicola and $V$. reichenbachiana are tetraploids $(2 n=20), V$. dirphya, $V$. oligyrtia and $V$. riviniana are octoploids $(2 n=40)$, and counts on $V$. sieheana suggest it is octoploid $(2 n=40)$ or dodecaploid $(2 n=60)$.

$V$. sieheana as hitherto circumscribed is the south-easternmost of the European blue-flowered woodland species (see map in Fig. 1). It has been attributed a mainly PontoCaucasian distribution, reaching in the west and north the Balkans from eastern Greece to Romania and Moldova, in the south the mountains of The Lebanon and Cyprus, and in the east the Caucasus and the temperate forests of northern Iran (Becker 1902, 1924; Yuzepchuk 1949; Coode and Cullen 1965; Valentine et al. 1968; Mouterde 1970; Meikle 1977; Raus 1986; Schmidt 1992). The distribution of $V$. sieheana overlaps with that of $V$. riviniana only in the Balkans, in a belt from Greece to Moldova, while it is nested almost completely within the range of the more widely distributed $V$. reichenbachiana. $V$. sieheana was originally described (Becker 1902) based on a number of syntypes from the Crimea, Moldova (Bessarabia) and Turkey (Cilicia, Anatolia, Bithynia), from which a lectotype (Turkey: Cilicia: Mersina [=present-day İçel]. W. Siehe s.n. LE!) was later selected (Nikitin 1998). The Crimean plants had already been described under the illegitimate name $V$. neglecta M. Bieb., non F.W. Schmidt (Marschall von Bieberstein 1808). Later, Becker (1924) also included in $V$. sieheana (as $V$. riviniana ssp. neglecta) plants from the Caspian region (Azerbaijan: Lenkoran and Iran: Gorgān). These Caspian plants had previously been described as V. sylvatica var. caspia Rupr. (Ruprecht 1869) and were later raised to the species level, V. caspia (Rupr.) Freyn (1902). The wide delimitation of $V$. sieheana (sensu Becker 1924) has subsequently been adopted by most later authors (e.g. Coode and Cullen 1965; Schmidt 1992; Valentine 1962; Yuzepchuk 1949). However, such a wide delimitation of $V$. sieheana appears to be problematic in certain respects.

Firstly, two chromosome numbers, $2 n=40$ and $2 n=60$, corresponding to the octo- and dodecaploid levels (Marcussen and Nordal 1998; Nordal and Jonsell 1998), have been reported in specimens attributed to $V$. sieheana. The number $2 n=60$ has been reported from northern Turkey, Greece and Cyprus (Harvey in Valentine 1962; Livaniou-Tiniakou 1991; Tiniakou 1991a). The number $2 n=40$, on the other hand, is disjunctive, with reports from one Georgian (as $n=20$ ) (Clausen 1927) and four Greek populations (van Loon and Oudemans 1982; Tiniakou 1991a). These reports for $V$. sieheana are in contrast with the uniformity in chromosome numbers found in all other known species of the section, disregarding the occurrence of B-chromosomes (Marcussen et al. 2010).

Secondly, V. sieheana appears as a morphologically rather variable species, particularly in stipule shape and fimbriation and in leaf blade index. The most spectacular character that seems to form an interesting geographical pattern in this species complex is corolla colour. Plants with whitish corollas (i.e. "V. neglecta" and V. caspia) have been reported solely from Crimea, the Caucasus, and from the south Caspian coast (Becker 1924; Freyn 1902; Meikle 1977; Mouterde 1970; Raus 1986; Ruprecht 1869; Schmidt 1992). On the other hand, plants from Greece, Cyprus, Turkey and the Middle East, i.e. V. sieheana in the strict sense (Nikitin 1998), are reported to have invariably lavender blue flowers (M. Dinç, personal communication; Meikle 1977; Mouterde 1970; Raus 1986). Obscuring the picture are numerous reports from the Balkans of 'transitional' forms between $V$. sieheana and $V$. riviniana (Becker 1922, 1924; Raus 1986; Tiniakou 1991a). Tiniakou (1991a) found Greek plants with the same chromosome number as $V$. riviniana, $2 n=40$, that according to her showed 'intermediate morphological characters between $V$. sieheana and $V$. riviniana'. Whether these plants represent hybrids or novel species is not clear.

This study aimed to resolve these apparent ambiguities within the $V$. sieheana complex. Specifically addressed questions were:

1. Can we confirm the occurrence of two cytotypes $(2 n=40$ and $2 n=60)$ in V. sieheana?

2. If the answer to question 1 is 'yes', are the cytotypes associated with geographic distribution or with differences in morphology (i.e. corolla colour and leaf shape)?

3. Are the cytotypes reproductively isolated from each other and from other related taxa? 


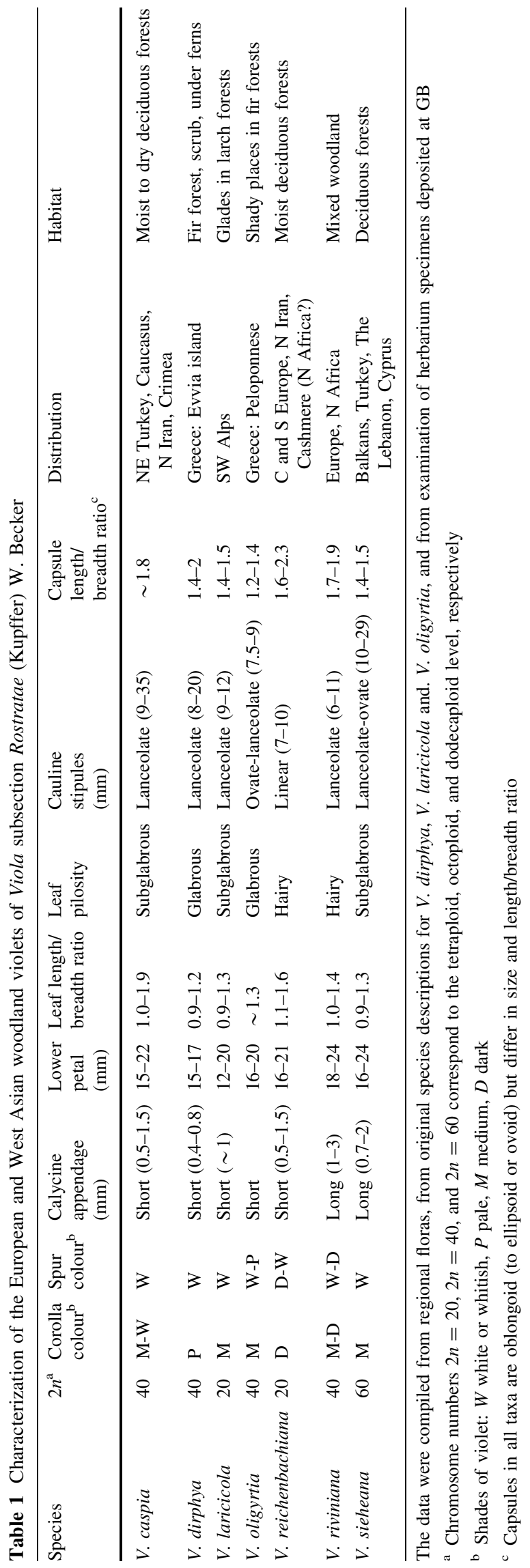

4. Does the previously described $V$. caspia deserve recognition as a distinct species, or is it part of V. sieheana?

In order to evaluate these questions, all relevant taxa known from the Balkans to the Caucasus were sampled and analysed. In addition to $V$. sieheana s. lat., this included $V$. dirphya, $V$. oligyrtia, $V$. reichenbachiana and $V$. riviniana.

Variation was analysed using allozyme electrophoresis, morphometry, ploidy level estimates by flow cytometry, and chromosome counts. Hybridization experiments were conducted to estimate possible gene flow within and between putative taxa; this approach has been used successfully to estimate relationships within the genus (e.g. Bamford and Gershoy 1930; Harvey 1966; McPherson and Packer 1974; Moore and Harvey 1961; Schmidt 1961; Valentine 1975). Allozyme electrophoresis was chosen as the molecular approach because it has proved to be a reliable tool in unveiling variation patterns and systematic relationships within species and species groups in Viola (Batista and Sosa 2003; Culley and Wolfe 2001; Li et al. 2000; Marcussen 2003a; Marcussen and Nordal 1998; Marcussen and Borgen 2000; Marcussen et al. 2001; Nordal and Jonsell 1998).

\section{Materials and methods}

\section{Plant materials}

The material included a total of 298 plants from 59 sites (see supplementary material A), collected from 2000 to 2004. V. sieheana s. str. was collected from representative sites in Turkey, Greece and Cyprus (34 sites, 150 individuals), and $V$. caspia from sites in Azerbaijan and Turkey (12 sites, 35 individuals). Additionally, the three species V. dirphya (4 sites, 28 individuals), V. oligyrtia (2 sites, 15 individuals), $V$. riviniana (3 sites, 11 individuals) from Greece, and V. reichenbachiana (15 sites, 50 individuals) from Greece and Turkey were included. V. sieheana and $V$. reichenbachiana co-occurred in several of the Greek sites (indicated with asterisks), and hybrids were detected in three of them (10 individuals). Vouchers of all analysed taxa and chromosome number determinations are deposited in the Botanical Museum, Natural History Museum, University of Oslo $(\mathrm{O})$.

\section{Allozyme electrophoresis}

Eight enzyme systems were analysed: aspartate aminotransferase (AAT), aconitase (ACO), aminopeptidase (AMP), glucose-6-phosphate isomerase (GPI; 'PGI'), isocitrate dehydrogenase (IDH), malate dehydrogenase 


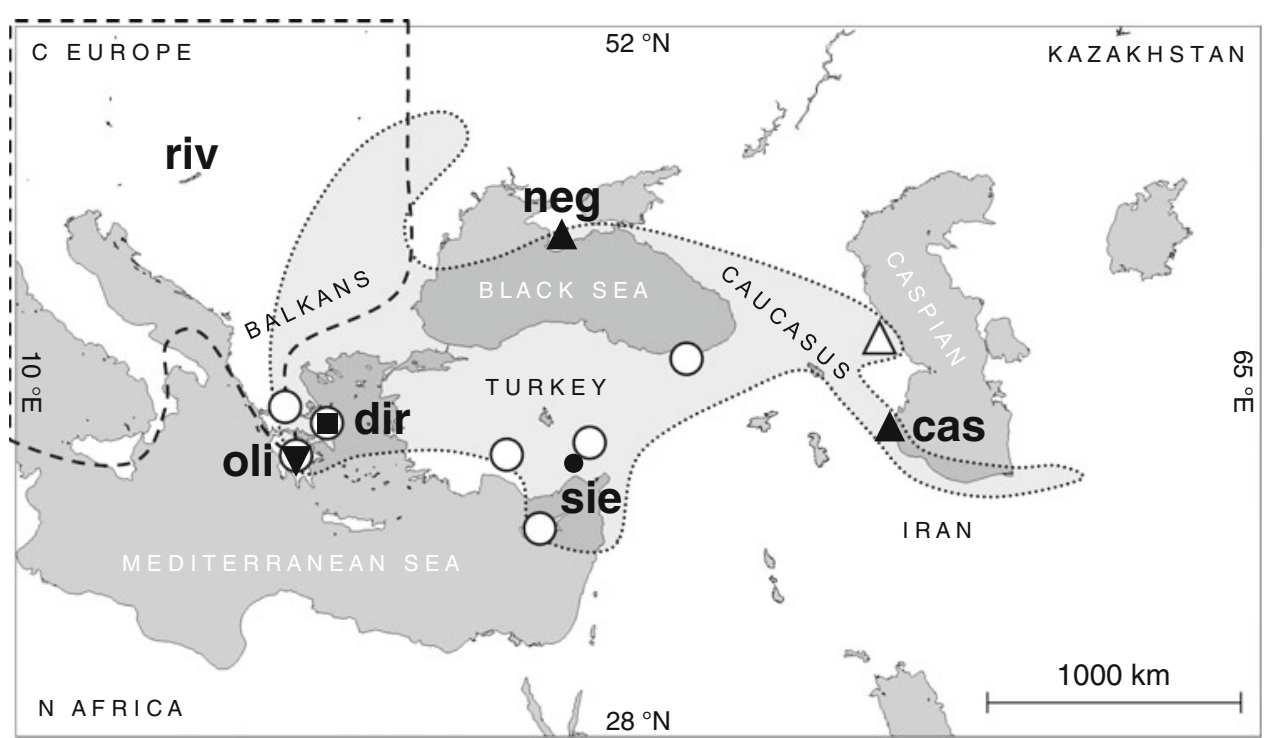

Fig. 1 Approximate distribution of the V. sieheana complex (dotted line). Sampled areas (may include several populations) of $V$. sieheana s. str. (circles) and V. caspia (triangle) are marked with large, unfilled symbols (cf. supplementary material A). The type localities of $V$. sylvatica Fr. var. caspia Rupr. (Lenkoran), "V. neglecta” M. Bieb.
(Ukraine: Crimea) and V. sieheana W. Becker (Turkey: Cilicia), and for the two narrow endemics $V$. dirphya A. Tiniakou and $V$. oligyrtia A. Tiniakou are indicated by smaller, filled symbols. The approximate southeastern limit of $V$. riviniana $\mathrm{Rchb}$. is drawn with a broken line; $V$. reichenbachiana occurs throughout the range of the other taxa
(MDH), phosphoglucomutase (PGM), and shikimate dehydrogenase (SDH; 'SKD'). Due to difficult band levels and indistinctness, AMP was analysed only in V. sieheana s. str. and IDH only in V. caspia.

In order to avoid the problems associated with sliming often encountered in Viola, the use of very young and still cigar-shaped leaves was imperative for successful analysis. Leaves were crushed in four drops of grinding buffer (Morden et al. 1987) and the homogenates centrifuged at maximum speed $(10,000 / \mathrm{min})$ and subsequently stored at $-80^{\circ} \mathrm{C}$. The supernatant was loaded in $0.7 \times 3 \mathrm{~mm}$ (about $25 \mu \mathrm{l}$ ) wells in the gel (62 g hydrolysed starch and $14 \mathrm{~g}$ sucrose per $500 \mathrm{ml}$ gel buffer). Gels were run at $4^{\circ} \mathrm{C}$ for 5-6 h using buffer system 6 of Wendel and Weeden (1989) with modification (pH 8.3; electrode buffer: lithium borate, $12.4 \mathrm{~g} \mathrm{~B}(\mathrm{OH})_{3} / 1 \mathrm{H}_{2} \mathrm{O}$; gel buffer: Tris citrate, $6.1 \mathrm{~g}$ Tris/ $\mathrm{H}_{2} \mathrm{O}$ ) for gels stained for AAT, AMP and GPI, and buffer system 1 with modification (histidine citrate, $10.1 \mathrm{~g}$ histidine/ $\mathrm{H}_{2} \mathrm{O}$; $\mathrm{pH}$ 6.5) for gels stained for IDH, PGM and SDH. Due to allopolyploidy and the confounding of homoeologues, allele frequencies could not be calculated. Allelic, homomeric bands, labelled alphabetically from the most anodal position, were scored as anonymous $(0,1)$ markers. The data set was analysed by the UPGMA (Sokal and Michener 1958) and PCO (Gower 1966) procedures using the NTSYSpc-2.02h package (Rohlf 1997). The UPGMA analysis included all specimens except hybrids, while the PCO analysis, based on Dice's similarity, included hybrids but excluded specimens of $V$. dirphya and $V$. oligyrtia purely for visibility purposes.

Ploidy analyses: chromosome counts and flow cytometry

Ploidy level was estimated using flow cytometry on a subset of 152 individuals representing all taxa (see supplementary material A). The flow cytometry analysis was performed by Plant Cytometry Services, The Netherlands. DAPI-stained cell nucleus isolates (Arumuganathan and Earle 1991) were filtered, run through the flow cytometer (PAS II, Partec) and their fluorescence measured using a photomultiplier. No internal standard was used, but plants representing the different ploidy levels were used as external calibration standards for the other measurements, i.e. for $2 n=20 \mathrm{~V}$. mirabilis L. (TM419, Norway), for $2 n=40 \mathrm{~V}$. riviniana (TMx013A, $\mathrm{F}_{1}$ cross), and for $2 n=60$ two individuals of $V$. sieheana from Cyprus (TM469-4 and TM476-2). The fluorescence of a leaf sample is proportional to the DNA content (Husband and Schemske 1998). Presented here are relative fluorescence values equivalent to relative DNA contents, expressed as channel numbers (Bennett et al. 2000). These estimates were calibrated with actual chromosome counts of six individuals.

Chromosomes were counted in six plants, three of $V$. sieheana and three of $V$. caspia, in mitotic metaphase. Three or more root-tips were checked per plant. Root tips 
were pretreated with either $2 \mathrm{mM}$ 8-hydroxyquinoline for $2 \mathrm{~h}$ at $20^{\circ} \mathrm{C}$ plus $2 \mathrm{~h}$ at $4^{\circ} \mathrm{C}$, or a saturated solution of 1-bromonaphthalene in water for $24 \mathrm{~h}$ at $4^{\circ} \mathrm{C}$, fixed in absolute ethanol/acetic acid (3:1), transferred to $70 \%$ ethanol, and stored in a freezer. Fixed root tips were hydrolysed in $1 \mathrm{~N} \mathrm{HCl}\left(60^{\circ} \mathrm{C}\right)$ for $8 \mathrm{~min}$, stained in Feulgen stain for $30 \mathrm{~min}$, and squashed in $45 \%$ acetic acid. Slides are kept at the Botanical Museum, Natural History Museum, University of Oslo.

\section{Crossing experiments}

A total of 90 cross-pollinations were made in a glasshouse, of which 47 gave 113 mature $\mathrm{F}_{1}$ plants. All hybrid combinations were attempted but, most likely due to a low number of flowers and periodical high mortality, no data became available for the three hybrid combinations $V$. dirphy$a \times$ reichenbachiana, $V$. oligyrtia $\times$ reichenbachiana, and $V$. oligyrtia $\times$ riviniana, or from within-species crosses of $V$. dirphya, V. oligyrtia and $V$. reichenbachiana.

Chasmogamous flowering was obtained after 4-6 weeks of vernalization $\left(9^{\circ} \mathrm{C}, 8 \mathrm{~h}\right.$ day/16 h night). Pollen was dissected out of the anthers of the 'male' flower and transferred to the receptive stigmatic cavity of the 'female' flower using a tooth stick (dyed black to better view the pollen). Anther size and their position close to the ovary did not allow emasculation; instead the spurred petal, onto which pollen sprinkles and causes delayed self-pollination, was removed. Pollinated flowers were bagged to prevent further pollination and to capture expelled ripe seeds. Seeds were sown on wet filter paper treated with gibberellic acid (Blaxland 1996) immediately after the capsule had opened (about 4 weeks after fertilization). Germination took 2-6 weeks and yielded mature plants with cleistogamous flowers after another 8-12 weeks.

For practical reasons estimates of fertility were made on developing capsules derived from cleistogamous flowers, as seed/ovule ratios. The use of self-fertilizing cleistogamous flowers, produced in great abundance in cultivation, was here preferred to chasmogamous flowers, which are typically few and require vernalization to form and manual pollination to set seed.

\section{Results}

\section{Allozyme variation}

The obtained banding patterns were in accordance with enzyme subunit composition known from previous studies in vascular plants: ACO, AMP, PGM, and SDH proved monomeric, and AAT, GPI, IDH, and $\mathrm{MDH}$ dimeric (Kephart 1990). As expected from earlier studies in polyploids, and in Viola in particular (Marcussen 2003a; Marcussen and Nordal 1998; Nordal and Jonsell 1998), fixed heterozygosity was expressed in all the taxa in nearly all systems (not SDH) and the number of bands increased with ploidy level (see supplementary material B).

A total of 38 markers were obtained, of which eight were fixed or nearly so in all taxa and another seven were specific to single taxa. AMP was interpretable only for $V$. sieheana and gave another four markers of which three showed variation. IDH was unstable and banding patterns were interpreted only in $V$. caspia. All six taxa investigated, including $V$. caspia and $V$. sieheana, were allozymically distinct (see supplementary material B). However, $V$. reichenbachiana and $V$. riviniana were allozymically less distinct than the other taxa and differed primarily in the number of bands (e.g. in AAT, GPI, PGM) and in the presence/absence of some bands ( $V$. reichenbachiana: $G_{p i}^{a}, G p i^{f}, S d h^{b}$; V. riviniana: $\left.\mathrm{Pgm}^{e}, \mathrm{Pgm}^{f}, \mathrm{Pgm}^{k}\right)$. Considerable variation was found in all taxa except in the two Greek endemics which showed fixed (V. oligyrtia) and almost fixed banding patterns ( $V$. dirphya; presence/ absence of $A c o^{b}$ ). The two corolla colour morphs of $V$. caspia proved allozymically distinct and differed in the presence/absence of seven allozyme markers: $A a t^{c}, A_{c o}{ }^{a}$, $A c o^{e}, A c o^{f}, \mathrm{Gpi}^{h}$, and $I d h^{c}$ were specific to the whitishflowered morph and $G p i^{b}, G p i^{i}$ and $I d h^{b}$ to the blue-flowered morph. Intermediates, interpreted as local introgressants, were found only in one disturbed site, close to the village of Qusar near Quba (TM-236). V. reichenbachiana proved particularly variable, as indicated by the low average band frequency (0.67). Also $V$. sieheana s. str. proved variable, with an average band frequency 0.74 , but its Greek populations were comparatively depauperate in variation (Table 2), with allozyme variation found only within the mainland Karditsa enclave; the remaining four enclaves were fixed for different multilocus phenotypes. $A c o^{e}$ and $\mathrm{Gpi}^{e}$ were only observed in Greece, but here they occurred with relatively high frequencies. Allozymically, $V$. reichenbachiana $\times$ sieheana was generally very similar to $V$. sieheana (see supplementary material B) but usually identifiable by the expression of one of three reichenbachiana markers (Aat ${ }^{a}, \mathrm{Pgm}^{a}$, and $S d h^{b}$ ).

The allozyme data were subjected to two multivariate analyses, an UPGMA analysis (Fig. 2) and a PCO analysis (Fig. 3). The UPGMA analysis included all specimens except hybrids (i.e. the $V$. caspia introgressant population and the $F_{1}$ hybrid $V$. reichenbachiana $\times$ sieheana), 281 individuals in total. The PCO analysis included 253 individuals of both pure species and hybrids, but $V$. dirphya and $V$. oligyrtia, already shown as distinct in the UPGMA analysis, were omitted for better resolution. The two analyses were congruent in showing the taxa as generally distinct, except for $V$. reichenbachiana and $V$. riviniana 

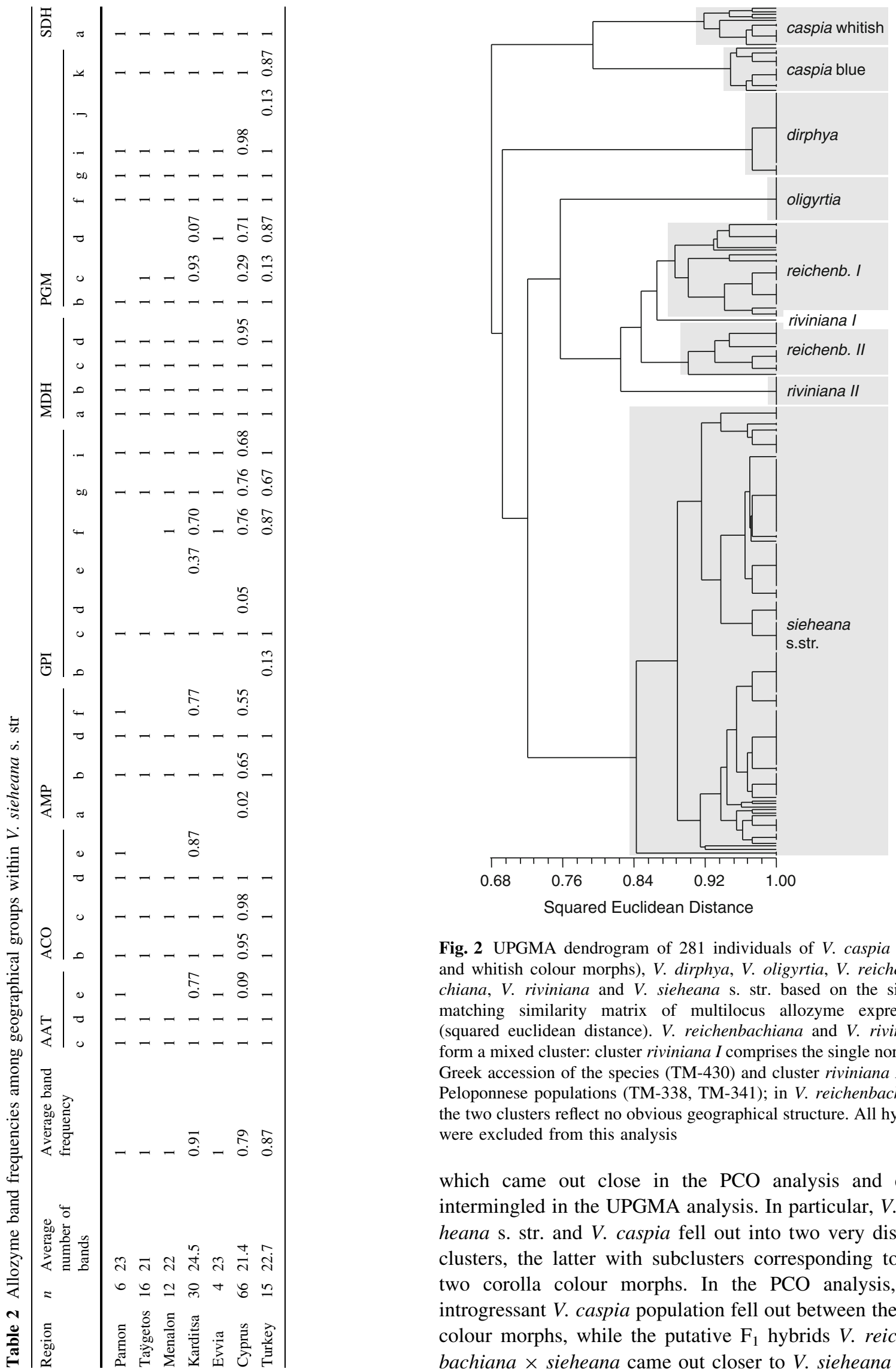

Fig. 2 UPGMA dendrogram of 281 individuals of $V$. caspia (blue and whitish colour morphs), $V$. dirphya, $V$. oligyrtia, $V$. reichenbachiana, $V$. riviniana and $V$. sieheana s. str. based on the simple matching similarity matrix of multilocus allozyme expression (squared euclidean distance). V. reichenbachiana and V. riviniana form a mixed cluster: cluster riviniana $I$ comprises the single northern Greek accession of the species (TM-430) and cluster riviniana II the Peloponnese populations (TM-338, TM-341); in V. reichenbachiana the two clusters reflect no obvious geographical structure. All hybrids were excluded from this analysis

which came out close in the PCO analysis and even intermingled in the UPGMA analysis. In particular, $V$. sieheana s. str. and $V$. caspia fell out into two very distinct clusters, the latter with subclusters corresponding to the two corolla colour morphs. In the PCO analysis, the introgressant $V$. caspia population fell out between the two colour morphs, while the putative $\mathrm{F}_{1}$ hybrids $V$. reichenbachiana $\times$ sieheana came out closer to $V$. sieheana than 


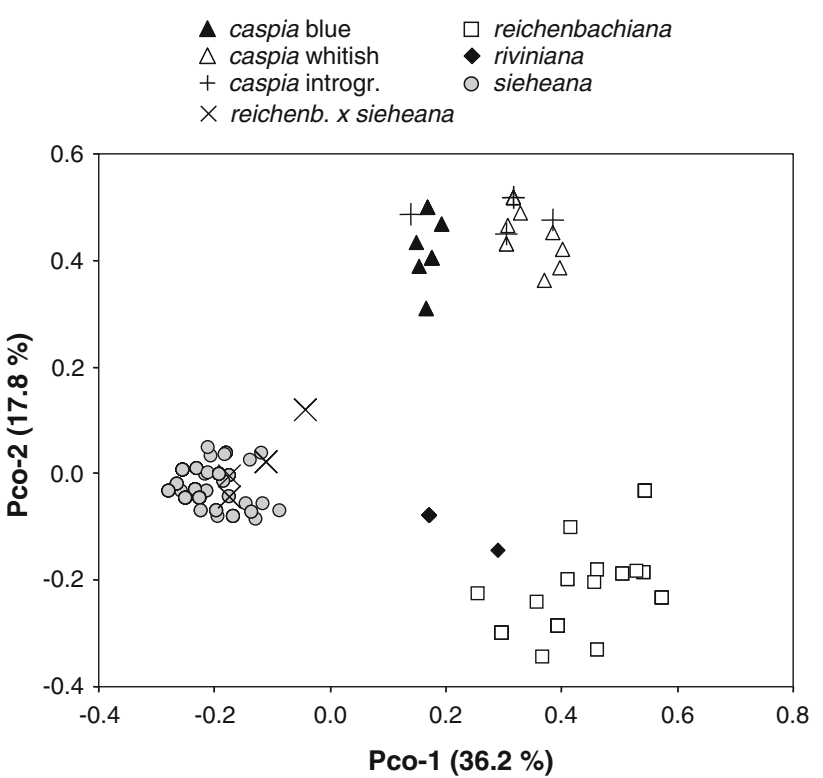

Fig. 3 Scatter plot of the two first PCO axes based on a Dice's similarity matrix of 253 individual multilocus allozyme phenotypes of $V$. caspia, broken down into its two morphs (blue and whitish) and one introgressed population (TM-236), V. reichenbachiana, $V$. riviniana, $V$. sieheana $\mathrm{s}$. str., and the sterile hybrid $V$. reichenbachiana $\times$ sieheana. PCO axes 1 and 2 extracted $36.2 \%$ and $17.8 \%$ of the variance, respectively

to $V$. reichenbachiana as a result of the parents' uneven ploidy levels.

Ploidy levels

Chromosome counts and flow cytometry (see supplementary material A) gave concordant results. Individuals with $2 n=20,2 n=40$, and $2 n=60$ had the corresponding channel numbers $50,94 \pm 2$, and $140 \pm 3$, respectively. The slime content resulted in a higher variation between samples than normal due to the difficulty in obtaining a constant flow of nuclei in the flow cytometer. All plants of $V$. sieheana s. str. were dodecaploid $(2 n=60)$ and all plants of $V$. caspia were octoploid $(2 n=40)$. Flow cytometric data confirmed previously published counts in
$V$. dirphya, $V$. oligyrtia and $V$. riviniana (all $2 n=40$ ), and $V$. reichenbachiana $(2 n=20)$. Based on flow cytometry, the hybrid $V$. reichenbachiana $\times$ sieheana was octoploid $(2 n=40)$, as expected from the parental numbers.

Crossing experiments and interfertility

The results of the crossing experiments are shown in Table 3. Except for $V$. dirphya $\times$ sieheana and $V$. reichenbachiana $\times$ riviniana, which were slightly fertile and produced occasional cleistogamous capsules with one or two seeds, the interspecific hybrids were highly sterile and produced high numbers of aborting cleistogamous capsules. Within-species crosses gave fully fertile offspring, except those between the two colour morphs of $V$. caspia. For $V$. caspia a total of 36 crossed specimens were raised from seed, of which seven were within-morph crosses and 29 were between-morph crosses. Seed/ovule ratios were calculated based on one to three unripe capsules per specimen and the two cross types statistically compared in a two-tailed $t$ test. Between-morph crossed specimens had lower fertility (seed/ovule ratio 0.73) than within-subspecies crosses (0.87). This difference was statistically highly significant $\left(p=0.0053, t_{\text {two-tailed }}=2.9806, \mathrm{df}=34\right)$.

\section{Morphology}

Although $V$. caspia and $V$. sieheana appeared to be morphologically similar, delimitating characters existed for the two taxa (Figs. 4 and 5; Table 4).

Capsule shape (Figs. 4c, 5c), especially valve width, was a good delimitating character that appeared to be fairly constant within each of the two taxa. Both taxa had oblongoid capsules, but in V. caspia the capsule valves were about $2 \mathrm{~mm}$ wide as compared to about $3 \mathrm{~mm}$ in $V$. sieheana s. str. This is believed to be a good field character as capsules were often present on the plants when in the cleistogamous phase, as dried open capsules on old or withered floriferous stems, or as loose capsule valves that had spilled to the ground. Owing to a more regular seed set

Table 3 Cleistogamous fertility (seed/ovule ratio) in 15 artificially obtained hybrid combinations $(n=78)$

\begin{tabular}{|c|c|c|c|c|c|c|}
\hline & V. caspia & V. dirphya & V. oligyrtia & V. reichenbachiana & $V$. riviniana & V. sieheana \\
\hline V. caspia & Fertile & & & & & \\
\hline V. dirphya & Sterile & Hybrids not obtained & & & & \\
\hline V. oligyrtia & Sterile & Sterile & Hybrids not obtained & & & \\
\hline V. reichenbachiana & Sterile & Hybrids not obtained & Hybrids not obtained & Hybrids not obtained & & \\
\hline V. riviniana & Sterile & Sterile & Hybrids not obtained & Semifertile & Fertile & \\
\hline$V$. sieheana & Sterile & Semifertile & Sterile & Sterile & Sterile & Fertile \\
\hline
\end{tabular}

Fertile $>50 \%$; semifertile $<10 \%$ 
Fig. 4 Morphology of V. caspia (Rupr.) Freyn, drawn from plants grown in a glasshouse. $a, b$ Sepals of chasmogamous flower, in lateral (a) and dorsal (b) views; $c$ capsule of cleistogamous flower; $d$ cauline stipules from four individuals, from lower (left) to upper (right); $e, f$ lateral stems with cleistogamous flowers and capsules.

Scale circle $1 \mathrm{~cm}$. Drawings by

T. Marcussen
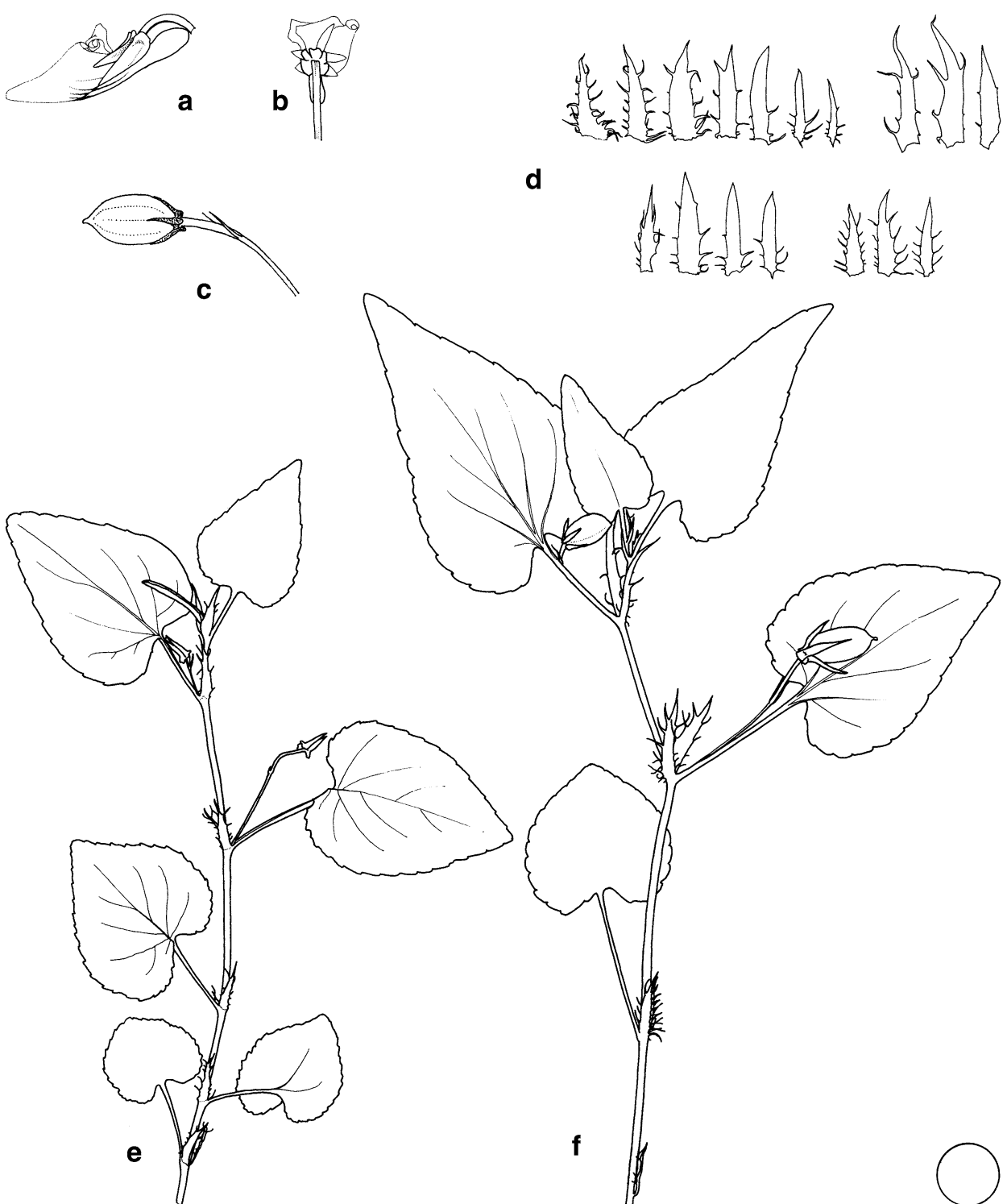

d

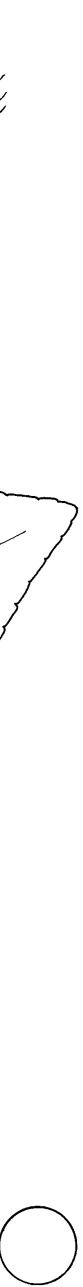

in cleistogamous flowers than in chasmogamous ones, the morphology of 'cleistogamous' capsules was more stable.

Size and shape of calycine appendages (Figs. 4a, b; 5a, b), which are more prominent in $V$. sieheana than in V. caspia, was a useful character during the chasmogamous phase in spring but was of limited use later in the season due to considerable seasonal variation. As often in Viola, sepals including appendages were well-developed in chasmogamous flowers but gradually decreased in size during the cleistogamous phase.

Differences both in stipule shape (Figs. 4d, 5d) and leaf blade index and shape (Figs. 4e, f; 5e, f) were observed between the two taxa. However, as in many taxa of subsection Rostratae (Bergdolt 1932; Marcussen 2007), these characters were seasonally variable and proved also extremely plastic and prone to much variation among, as well as within, populations and individuals. In both taxa the basal rosette leaves were relatively broad while the cauline leaves were progressively narrower and the petioles shorter towards the apex of the stems. Very characteristic of $V$. caspia, though not always expressed, was the acuminate to attenuate apex of the upper cauline leaves; this was visible in one of Ruprecht's syntypes and also noted by him in the diagnosis: 'foliis cauliniis superioribus apice magis protracto, attenuato-acuminato' (Ruprecht 1869). Similarly, the stipules of the basal rosette were in general scaly and distinctly fimbriate in both taxa, whereas the cauline stipules were progressively larger, more leaf-like, and with less pronounced fimbriation towards the apex of the stems.

Finally, the two taxa often differed in corolla colour. $V$. sieheana always had lavender blue corollas while $V$. caspia had either whitish or lavender blue corollas. In the whitish-flowered morph of $V$. caspia the faint hue and dark lilac veins of the spurred petal showed that the whitish- 
flowered morph is not analogous to the totally anthocyanfree forms otherwise common in the genus, e.g. within V. alba Besser (Marcussen 2003a).

\section{Discussion}

The recognition of two species, $V$. sieheana and $V$. caspia

Based on our data, it is clear that the Ponto-Caucasian $V$. sieheana s. lat., as circumscribed in the literature (Becker 1902, 1910, 1924; Nikitin 1996; Raus 1986; Schmidt 1992; Yuzepchuk 1949), is an artificial assembly of taxa. The taxon breaks up into two main taxonomic entities that differ in morphology, in allozymic composition, and in chromosome number $(2 n=40$ and $2 n=60)$. These entities are also separated by weak prezygotic and postzygotic sterility barriers and appear to have different geographical distributions. The two entities are as distinct from each other as either is from their relatives $V$. reichenbachiana, $V$. riviniana, $V$. oligyrtia and $V$. dirphya. They should therefore be considered as two species, $V$. sieheana and V. caspia.

$V$. sieheana s. lat. was originally described by Becker (1902) based on a number of heterospecific syntypes, from among which a lectotype (Turkey: Cilicia: Mersina [=present-day İçel]. W. Siehe s.n. LE!) was later selected by Nikitin (1998). V. sieheana s. str. is recognized by having blue flowers, mostly ovate and dentate stipules, broad leaves, capsules with broad valves (Fig. 5; Table 4), and the chromosome number $2 n=60$.
Fig. 5 Morphology of $V$. sieheana W. Becker s. str., drawn from plants grown in a glasshouse. $a, b$ Sepals of chasmogamous flower, in lateral $(a)$ and dorsal (b) views; $c$ capsule of cleistogamous flower; $d$ cauline stipules from seven individuals, from lower (left) to upper (right); $e, f$ lateral stems with cleistogamous flowers and capsules. Scale circle $1 \mathrm{~cm}$. Drawings by $\mathrm{T}$. Marcussen
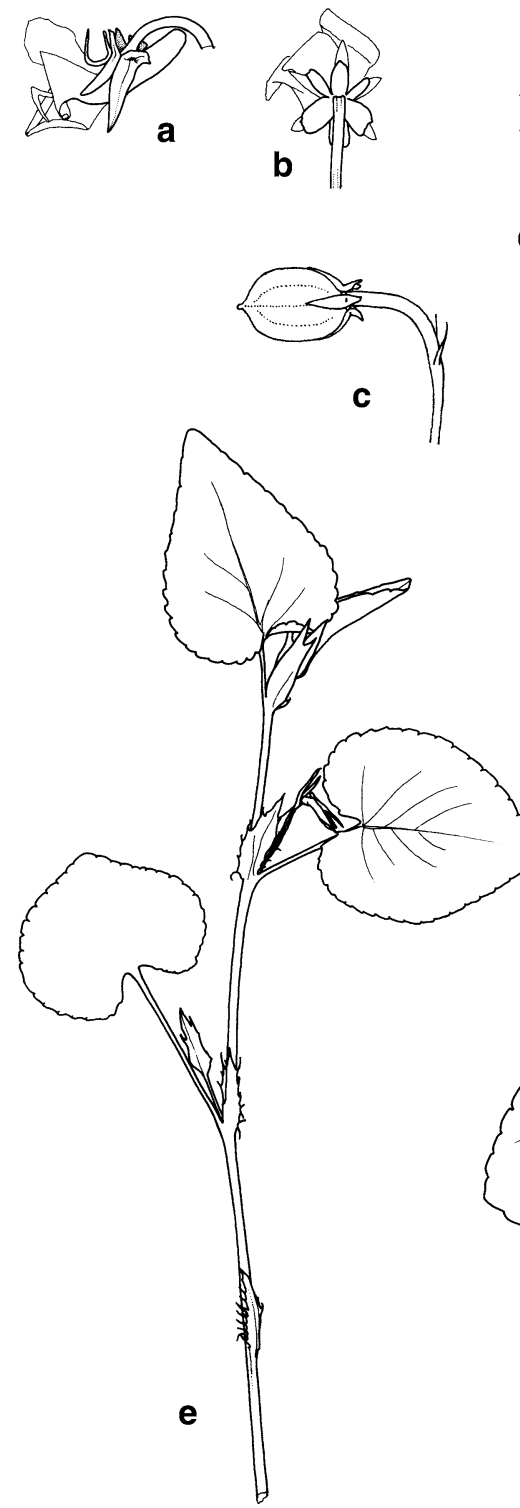
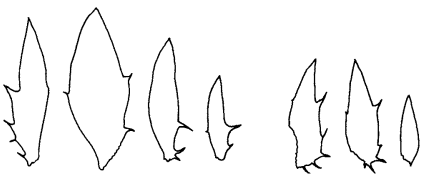

d

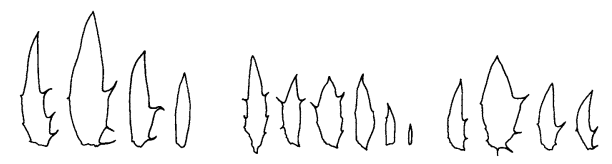

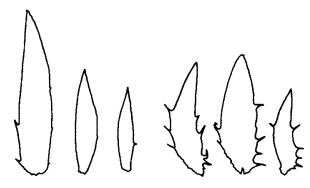
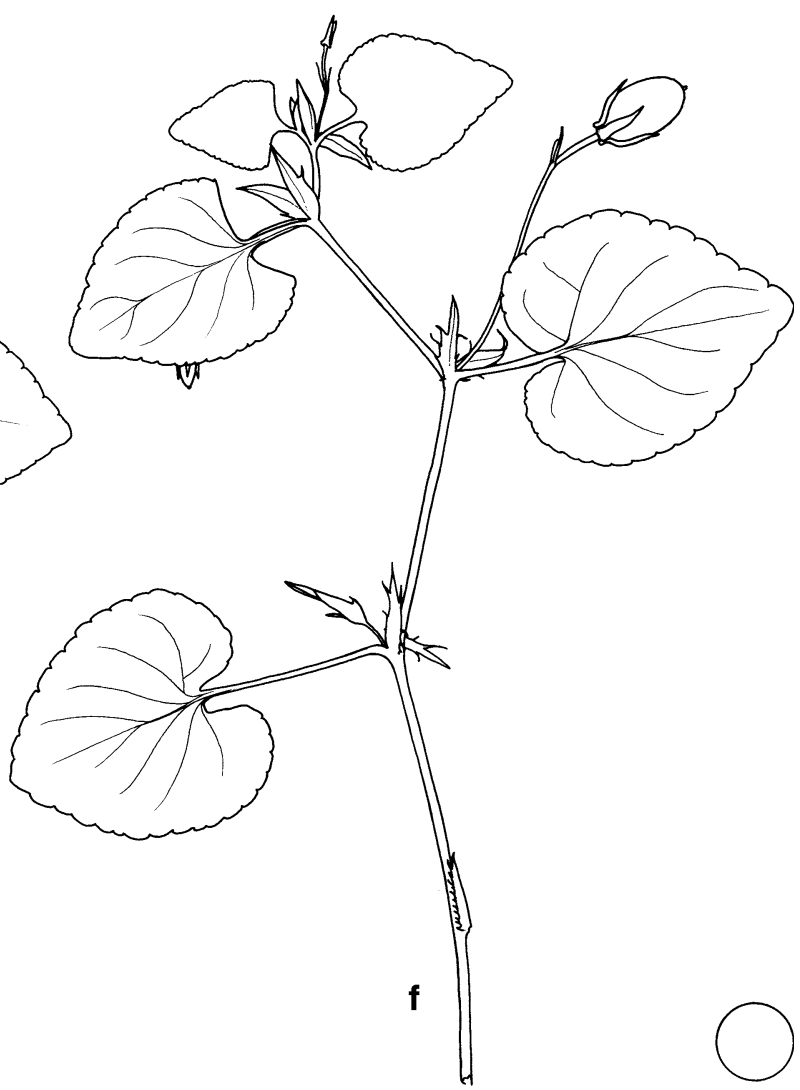
Table 4 Diagnostic morphological characters of $V$. sieheana s. str. and. V. caspia

\begin{tabular}{|c|c|c|}
\hline Discriminating character & V. caspia & V. sieheana s. str. \\
\hline Capsule shape (Figs. 4c, 5c) & Relatively narrow; each valve $2 \mathrm{~mm}$ wide & Relatively wide; each valve $3 \mathrm{~mm}$ wide \\
\hline $\begin{array}{l}\text { Calycine appendages of } \\
\text { chasmogamous flowers } \\
\text { (Figs. } 4 a, b, 5 a, b)\end{array}$ & $\begin{array}{l}\text { Relatively short }(0.5-1.5 \mathrm{~mm}) \text {, blunt at } \\
\text { apex, not protruding from the calyx by } \\
\text { more than } 30^{\circ} \text {; in rear view of the } \\
\text { flower the appendages have a 'crown- } \\
\text { like' appearance usually no more than } \\
3-4 \mathrm{~mm} \text { across and much less } \\
\text { prominent than in } V \text {. sieheana }\end{array}$ & $\begin{array}{l}\text { Relatively large }(0.7-2 \mathrm{~mm} \text {; but shorter } \\
\text { than in e.g. } V \text {. canina and } V \text {. riviniana }) \text {, } \\
\text { at apex usually finely and irregularly } \\
\text { toothed, protruding from the calyx by an } \\
\text { angle of up to } 90^{\circ} \text {; in rear view of the } \\
\text { flower the appendages have a } \\
\text { conspicuous 'crown-like' appearance, } \\
\text { usually at least } 4-5 \mathrm{~mm} \text { across }\end{array}$ \\
\hline Cauline stipules (Figs. 4d, 5d) & $\begin{array}{l}\text { Usually lanceolate, widest at base, long- } \\
\text { fimbriate }\end{array}$ & $\begin{array}{l}\text { Usually ovate, widest in lower half (thus } \\
\text { slightly narrowing towards base), } \\
\text { dentate }\end{array}$ \\
\hline Cauline leaves (Figs. 4e, f, 5e, f) & $\begin{array}{l}\text { Some of the upper cauline leaves often } \\
\text { extremely elongate and acuminate to } \\
\text { attenuate, up to twice as long as wide }\end{array}$ & $\begin{array}{l}\text { Upper cauline rarely very acuminate, } \\
\text { usually about } 1.3 \text { times as long as wide }\end{array}$ \\
\hline Corolla colour & $\begin{array}{l}\text { Lavender blue or almost white; in both } \\
\text { instances with dark veins on the lower } \\
\text { petal }\end{array}$ & $\begin{array}{l}\text { Lavender blue, with dark veins on the } \\
\text { lower petal }\end{array}$ \\
\hline
\end{tabular}

As noted already by Becker (1924), some plants are easily assigned to what we here recognize as $V$. caspia based on the original description (Ruprecht 1869) and our own data. $V$. caspia differs from $V$. sieheana in stipule shape and fimbriation, in having capsules with narrow valves (Figs. 4, 5), and in the chromosome number $2 n=40$. However, the most striking and characteristic feature separating $V$. caspia from $V$. sieheana as well as from all other western Eurasian species, is the sometimes extremely elongated and acuminate upper cauline leaves (Fig. 4; Table 4). The same feature was stated explicitly in Ruprecht's (1869) diagnosis of V. sylvatica var. caspia : 'foliis cauliniis superioribus apice magis protracto, attenuato-acuminato' and also corresponds well with the syntype material (Hohenacker s.n. leg. 1940 LE!) from which a lectotype of the name was selected by V. Nikitin in 1985. Ruprecht himself did not cite any material or collectors but original material was specifically mentioned by Becker (1924): 'Lenkoran: [...] in prov. Talysch leg. Hohenacker a. 1840 et culta in hort. bot. Petrop. (Orig. der V. silv. var. caspia Rupr., Ac. Sc. Petrop.)'. We are not aware that Nikitin's typification of $V$. caspia has ever been published and we therefore validate it here.

We have confirmed the occurrence of plants with both $2 n=40$ and $2 n=60$ within the $V$. sieheana aggregate. Clausen's (1927) $n=20$ counts in Georgian plants, repeated here for Azerbaijani plants, obviously refer to V. caspia. Tiniakou (1991a) reported $2 n=40$ in plants 'intermediate in morphology between $V$. riviniana and $V$. sieheana' from Greece (Párnon, Taÿgetos, Ménalon and Kardítsa) and treated them taxonomically as $V$. riviniana. Our findings suggest that these counts may refer to the sterile $\mathrm{F}_{1}$ hybrid between $V$. reichenbachiana $(2 n=20)$ and $V$. sieheana $(2 n=60)$, which is locally abundant where the parental species meet and has $2 n=40$ like $V$. riviniana (cf. supplementary material A and Table 3 ). The hybrid is morphologically almost indistinguishable from the higher-ploid parent, $V$. sieheana, but has, for example, a more pronounced pubescence on the leaves, reminiscent of the other parent. The distinction between $V$. riviniana and $V$. sieheana is in fact substantial, morphologically (Raus 1986) as well as genetically, as visualized by allozymes and the complete sterility of the hybrid (Table 3). This leaves no reason to assume that these two taxa are connected by 'transitional' forms, as implied by so many authors (Becker 1924; Raus 1986; Tiniakou 1991a). We suspect that part of the confusion has been inherited from the chaotic taxonomy of the woodland violets, where $V$. sieheana, for example, was included in $V$. riviniana for a while (e.g. Becker 1924). An incomplete knowledge and understanding of the morphological variability in the complex, in addition to the natural occurrence of interspecific hybrids, very likely have resulted in the taxonomic confusion (e.g. Marcussen 2007).

$V$. caspia falls into two rather distinct groups defined by allelic composition in four enzyme systems (AAT, ACO, GPI, and IDH) (Figs. 2 and 3, and supplementary material B). Surprisingly, this rather profound genetic distinction is not reflected in overall morphology except in corolla colour, which is either lavender blue or nearly white. Neither do the two corolla morphs appear to differ in habitat ecology: they both have wide ecological amplitudes that range from open wooded steppe to deep and moist beech forest. Although they are regionally sympatric in north-eastern Azerbaijan, they seldom cooccur within the same site, and pure populations are either 
entirely blue-flowered or entirely whitish-flowered. Our experimental crossings between the two morphs show that they are cross-compatible and that the offspring is fertile (seed/ovule ratio 0.73 ), though slightly less fertile than the offspring from crosses within the morphs (seed/ovule ratio 0.87). Thus, the two corolla colour morphs seem isolated by both prezygotic barriers, because hybridization rarely seems to happen, as well as postzygotic barriers, as indicated by a weak genetic incompatibility that results in lowered hybrid fertility. Also the strong allozymic differentiation is an indication of reproductive isolation. Within the context of the biological species concept (Mayr 1995), they may represent incipient species. Presumably, the differentiation of the two corolla colour morphs can be upheld if the whitish- and blue-flowered morphs attract different pollinators. If selection is strong enough, or the system stable enough over time, the hybrid will be less fit in spite of its cleistogamous selfing ability and the system might result in the local mosaic allopatry of the two morphs that we seem to observe. However, little is known about which pollinators $V$. caspia attracts, and much more information is needed about the origin, biology, ecology, and respective distributions of the two colour morphs before any taxonomic conclusion can be reached. Plants from a single site (TM-236), a pasture near the village of Çıləgir, showed clear signs of hybridization and recombination between the two colour morphs, in having intermediate, pale-blue flowers, high heterozygosity, and lowered fertility; this indicates that the selective forces upholding the two morphs are subtle and may break down in disturbed habitats.

It seems from the literature records that the whitishflowered morph is the more widespread of the two, with an almost continuous distribution from northern Iran via the Major Caucasus to Crimea (Becker 1924; Freyn 1902; Kupffer 1909; Marschall von Bieberstein 1808; Ruprecht 1869). No mention has been made of a bluecoloured morph within this region, which might indicate that it is confined to a smaller geographical area. However, collectors may very well have failed to note flower colour in Viola unless it differed from the familiar lavender blue colour, and as dried herbarium specimens tend to fade with age, so does this information. Therefore, visiting live populations at the time of flowering seems the only option to investigate the relative distribution of the two corolla colour morphs of $V$. caspia. Another complicating factor is that through most of its range, $V$. caspia is sympatric with $V$. reichenbachiana, which is normally blue-flowered but extremely difficult to distinguish from $V$. caspia when not in flower. At least in Azerbaijan and in northern Iran, these two species readily hybridize to form a sterile hybrid (N. Yousefi and T. Marcussen, unpublished data).
Allopolyploid origins

The allopolyploid relationships among the species of Viola subsection Rostratae in Europe have been investigated in a series of studies using chromosome cytology (Moore and Harvey 1961), low-copy nuclear gene phylogeny (van den Hof et al. 2008), and microsatellite markers (Hepenstrick 2009). Within the Rostratae it is not uncommon that hybrids between polyploids and their lower-ploid progenitors are not completely sterile and that gene flow may happen between the species. In Europe, this is evident in $V$. reichenbachiana $(4 x) \times$ riviniana $(8 x)$ and in $V$. canina $(8 x) \times$ lactea Sm. $(12 x)$ (Moore and Harvey 1961; Neuffer et al. 1999; Schöfer 1954; Valentine 1950). The former species pair also came out intermingled in our isozyme study (Figs. 2, 3), which may be due to their incomplete reproductive isolation. Our finding that also the artificial hybrid between $V$. sieheana $(12 x)$ and $V$. dirphya $(8 x)$ is semifertile (Table 3 ), indicates a similar compatibility between the genomes of these two taxa and points to $V$. dirphya as a possible parent of $V$. sieheana. However, the incomplete additivity in allozyme patterns of $V$. dirphya and $V$. sieheana and the high allelic diversity of $V$. sieheana suggest that such an origin could not have been recent and certainly could not have involved the single extant population of $V$. dirphya. As the co-occurrence of $V$. dirphya with $V$. sieheana is not rare (personal observation), hybridization and potential gene flow between the two species may have implications for the future management of the narrow endemic $V$. dirphya. An auto- or allopolyploid origin of $V$. dirphya from $V$. reichenbachiana, as postulated by Tiniakou (Livaniou-Tiniakou 1991), was in any case not supported by the isozyme data.

No hypotheses have been put forward about the allopolyploid origin of $V$. caspia. Chromosomes in polyploids are expected to decrease in size over time compared to the ancestral diploids, due to processes of genome downsizing (Leitch and Bennett 2004). In line with this, the 'considerably smaller' chromosomes of $V$. caspia compared to those of V. riviniana (Clausen 1927) seem to suggest that $V$. caspia is not a result of recent allopolyploidization. The differentiation into two genetically very different corolla colour morphs might also indicate the same.

\section{Distribution and biogeography}

$V$. sieheana s. str. and $V$. caspia appear to be largely allopatric based on available information. $V$. sieheana is the more western of the two and appears to have a main distribution in Turkey and in the Balkans, with isolated southern occurrences in Cyprus, Syria, and The Lebanon. $V$. caspia is more eastern, with a main distribution in the Caucasus, from where it extends south along the Caspian 
coast of northern Iran, and west to Crimea (Becker 1924; Kupffer 1909; Marschall von Bieberstein 1808; Ruprecht 1869). It is, however, uncertain how far $V$. sieheana extends eastwards, and $V$. caspia westwards. Their known distributions are allopatric but a lack of apparent geographic or climatic barriers in the area between them, i.e. in northeastern Turkey, suggests that the two species may occur in sympatry at least in this region. Indeed, the whiteflowered specimens observed near Trabzon, northeastern Turkey (G. Knoche, personal communication) were probably V. caspia.

The fact that plants from Crimea were V. caspia while plants from Romania and Moldova (Zelenetzky G!), located only some $500 \mathrm{~km}$ away, were $V$. sieheana s. str., has to be seen in connection with the phytogeographic history of the region. During the last glaciation (Valdai) the northern Balkans were almost deprived of nemoral forests, while continuous forests were found in great abundance in Turkey, Crimea, and the Caucasus (Dubatolov and Kosterin 2000; Fukarek et al. 1995; Grichuk 1992). The persistent steppe vegetation of the Ukrainian lowlands north and east of Crimea since the beginning of the Valdai glaciation has apparently blocked any postglacial immigration of woodland taxa such as $V$. caspia from a putative CrimeoCaucasian refugium (cf. Demesure et al. 1996). Most nemoral forest species seem to have colonized the northern Balkans from an Anatolian refugium in the south, where $V$. sieheana, but not $V$. caspia, has its main distribution. Immigration of $V$. sieheana into Greece from an Anatolian refugium in the east has already been suggested (cf. Livaniou-Tiniakou 1991), and the geographically isolated and allozymically depauperate populations of southwestern Greece are to be interpreted either as results of independent colonizations or as relics of a previously more widely distributed and allozymically more diverse population.

\section{Conclusions}

Based on information from ploidy levels, allozymes, and morphology, we conclude that the two cytotypes previously recognized within $V$. sieheana represent two species, $V$. sieheana s. str. $(2 n=60)$ and V. caspia $(2 n=40)$. The two species are morphologically and genetically distinct and also distinct from the other investigated species in the subsection Rostratae. V. sieheana has its main distribution in the eastern Balkans, Turkey, Cyprus, and The Lebanon, and $V$. caspia has its main distribution in the CaspioCaucasus region westwards to Crimea and, probably, northeastern Turkey. Natural hybrids are not reported and experimental hybrids were highly sterile.

Here we validate Nikitin's unpublished typification of the name V. caspia (Hohenacker s.n. leg. 1940 LE!).
V. caspia comprises two allozymically distinct groups. Morphologically, this distinction is only reflected in different corolla colours, whitish or blue. The two colour morphs show a local pattern of mosaic allopatry and rarely co-occur. They are cross-compatible but artificial intermorph crosses have slightly less fertile offspring than intramorph crosses. The two morphs may represent a first step in an ongoing radiation and speciation process, but without further knowledge of their biology and evolution, we regard taxonomic conclusions premature at present.

The dodecaploid $V$. sieheana is undoubtedly of allopolyploid origin, but the incomplete additivity in allozyme patterns and high allelic diversity indicate that its origin is not recent. Limited hybrid fertility points to the Greek endemic $V$. dirphya $(2 n=40)$ as a possible lower-ploid ancestor. For $V$. caspia the putative ancestors are unknown, but differentiation into two genetically distinct corolla colour morphs indicates that the origin of $V$. caspia is not recent either.

Acknowledgments This study was supported financially by a Ph.D. scholarship to T. Marcussen from the Norwegian Research Council (grant 135144/410), by the Nansen Foundation of the Norwegian Academy of Sciences (50/2001) and by the University of Oslo. We thank two anonymous reviewers for their comments and suggestions on an earlier draft of this article. We also thank the curators of the herbaria cited and to the collectors of additional plant material; G. Gusarova and the late V. V. Nikitin for help finding the lectotypes of $V$. caspia and $V$. sieheana, respectively; M. Dinç, A. Tiniakou and A. Strid for sharing their knowledge of the species in Turkey and Greece; N. A. Sivertsen, Y. Adigozalov, F. Fedorov and the other staff of the Norwegian Refugee Council in Baku, without whose help and contribution field-work in Azerbaijan would have been impossible; and last, but not least, my underpaid field companions G. Alfredsen, A. S. Guldahl, F. B. Johansen, L. Korslund and M. H. Lie for their unselfish and enthusiastic help during field-work.

Open Access This article is distributed under the terms of the Creative Commons Attribution Noncommercial License which permits any noncommercial use, distribution, and reproduction in any medium, provided the original author(s) and source are credited.

\section{References}

Arumuganathan K, Earle ED (1991) Estimation of nuclear DNA content of plants by flow cytometry. Plant Mol Biol Rep 9:229-233

Bamford R, Gershoy A (1930) Studies in North American violets II. The cytology of some sterile F1 violet hybrids. Bull Vermont Agric Exp Sta 235:1-53

Batista F, Sosa PA (2003) Allozyme diversity in natural populations of Viola palmensis Webb, Berth (Violaceae) from La Palma (Canary Islands): implications for conservation genetics. Ann Bot (Oxford) 90:725-733

Becker W (1902) Viola splendida et Viola sieheana spec. nov. 1902. Bull Herb Boissier sér 2 2:750-752

Becker W (1910) Violae europaeae. Verlag von C Heinrich, Dresden 
Becker W (1922) Zur Veilchenflora Bulgariens. Repert Spec Nov Regni Veget 18:141-142

Becker W (1924) Violae asiaticae et australenses IV. Beih Bot Centralbl Abt 2 40:20-68

Bennett MD, Bhandol P, Leitch IJ (2000) Nuclear DNA amounts in angiosperms and their modern uses -807 new estimates. Ann Bot (Oxford) 86:859-909

Bergdolt E (1932) Morphologische und physiologische Untersuchungen über Viola zugleich ein Betrag zur Lösung des Problems der Kleistogamie. Bot Abh 20:1-120

Blaxland K (1996) Violet germination. Bull Alpine Gard Soc 64:323-325

Clausen J (1927) Chromosome number and the relationship of species in the genus Viola. Ann Bot (Oxford) 61:677-714

Coode MJE, Cullen J (1965) Subgen. Viola. In: Davis PH (ed) Flora of Turkey and the East Aegean islands, vol 1. University Press, Edinburgh, pp 525-529

Culley TM, Wolfe AD (2001) Population genetic structure of the cleistogamous plant species Viola pubescens Aiton (Violaceae) as indicated by allozyme and ISSRs molecular markers. Heredity 86:545-556

Demesure B, Comps B, Petit RJ (1996) Chloroplast DNA phylogeography of the common beech (Fagus sylvatica L.) in Europe. Evolution 50:2515-2520

Dubatolov VV, Kosterin OE (2000) Nemoral species of Lepidoptera (Insecta) in Siberia: a novel view on their history and the timing of their range distributions. Entomol Fenn 11:141-166

Freyn J (1902) Plantae novae orientales IV. Verzeichnis der von P. Sintenis in Ost-Masenderan gesammelten Pflanzen. Bull Herb Boissier sér 2 2:840-851

Fukarek F, Hübel H, König P, Müller GK, Schuster R, Succow M (1995) Die grosse farbige Enzyklopädie Urania-Pflanzenreich, Vegetation, vol 5. Urania-Verlag, Leipzig

Gower JC (1966) Some distance properties of latent root and vector methods used in multivariate analysis. Biometrika 53:325-338

Grichuk VP (1992) Vegetation during the maximum cooling of the Last Glaciation. In: Frenzel B Pecsi M, Velichko AA (eds.) Atlas of Paleoclimates and Paleoenvironments of the Northern Hemisphere. Geographical Research Institute, Hungarian Academy of Science, and Gustav Fischer Verlag, Budapest, p 55 (map), p 123

Harvey MJ (1966) Cytotaxonomic relationships between the European and North American rostrate violets. New Phytol 65:469-476

Hepenstrick D (2009) Tracing allopolyploid evolution with microsatellites in Viola. Dissertation, Swiss Federal Research Institute, Zürich

Husband BC, Schemske DW (1998) Cytotype distribution at a diploid-tetraploid contact zone in Chamerion (Epilobium) angustifolium (Onagraceae). Am J Bot 85:1688-1694

Kephart SR (1990) Starch gel electrophoresis of plant isozymes: a comparative analysis of techniques. Am J Bot 77:693-712

Kupffer KR (1909) Violaceae. In: Kusnezow NI, Busch NA, Fomin AV (eds) Flora Caucasica Critica, vol 3(9). Tipografija K. Mattisena, Jurjev, pp 158-248

Leitch IJ, Bennett MD (2004) Genome downsizing in polyploid plants. Biol J Linn Soc 82:651-663

Li A, Wang KQ, Ge S (2000) Genetic diversity within and among populations of Viola tenuicornis with reference to sampling strategies. Acta Bot Sin 42:1069-1074

Livaniou-Tiniakou A (1991) Viosistimatiki meleti tou genous Viola section Viola (Violaceae) stin Ellada (in Greek, with English summary). Dissertation, University of Patras, Greece

Marcussen T (2003a) Evolution phylogeography and taxonomy within the Viola alba complex (Violaceae). Pl Syst Evol 237:51-74; erratum 239:169
Marcussen T (2003b) A new violet species (Violaceae) from the south-west Alps. Bot J Linn Soc 142:119-123

Marcussen T (2007) A critical revision of morphology in the Viola canina complex in Norway (in Norwegian, with English summary). Blyttia (J Nor Bot Soc) 65:195-207

Marcussen T, Borgen L (2000) Allozymic variation and relationships within Viola subsection Viola (Violaceae). Pl Syst Evol 223:29-57

Marcussen T, Karlsson T, Wind P, Jonsell B (2010) Violaceae. In: Karlsson T (ed) Flora Nordica, vol 6. The Bergius Foundation, Royal Swedish Academy of Sciences, Stockholm, pp 12-52

Marcussen T, Nordal I (1998) Viola suavis, a new species in the Nordic flora, with analyses of the relation to other species in the subsection Viola (Violaceae). Nordic J Bot 18:221-237

Marcussen T, Borgen L, Nordal I (2001) Viola hirta (Violaceae) and its relatives in Norway. Nordic J Bot 21:5-17

Marschall von Bieberstein LBF (1808) Viola neglecta. In: Flora taurico-caucasica, vol 1. Typis Academicis, Charkoviae, p 172

Mayr E (1995) Species classification and evolution. In: Arai R, Kato M, Doi Y (eds) Biodiversity and evolution. National Science Museum Foundation, Tokyo, pp 3-12

McPherson GD, Packer JG (1974) A contribution to the taxonomy of Viola adunca. Can J Bot 52:895-902

Meikle RD (1977) Flora of Cyprus, Part 1. The Bentham-Moxon Trust, Royal Botanic Gardens, Kew

Moore DM, Harvey MJ (1961) Cytogenetic relationships of Viola lactea $\mathrm{Sm}$. and other West European arosulate species. New Phytol 60:85-95

Morden CW, Doebley J, Schertz K (1987) A manual of techniques for starch gel electrophoresis of Sorghum isozymes. The Texas Agricultural Experimental Station, The Texas A and M University System, Texas

Mouterde S (1970) Viola L. In: Nouvelle flore du Liban et de la Syrie, vol 2. Dar El-Machreq Éditeurs, Beyrouth, pp 531-535

Neuffer B, Auge H, Mesch H, Amarell U, Brandl R (1999) Spread of violets in polluted pine forests: morphological and molecular evidence for the ecological importance of interspecific hybridization. Mol Ecol 8:365-377

Nikitin VV (1996) Violaceae. In: Tzvelev NN (ed) Flora Europae orientalis/Flora vostocznoj Evropy, vol 9. Magnoliopsida. Mir i Semia-95, St Petersburg, pp 180-205

Nikitin VV (1998) Viola in the Caucasian flora (in Russian). Novosti Sist Vyssh Rast 31:202-231

Nordal I, Jonsell B (1998) A phylogeographic analysis of Viola rupestris: three post-glacial immigration routes into the Nordic area? Bot J Linn Soc 128:105-122

Raus T (1986) Viola L. In: Strid A (ed) Mountain Flora of Greece, vol 1. University Press, Cambridge, pp 608-640

Rohlf FJ (1997) NTSYS-pc: numerical taxonomy and multivariate analysis system, version 20202 h. Exeter Software, Setauket, New York

Ruprecht FJ (1869) Flora Caucasi Pars I. Mém Acad Imp Sci Saint Pétersbourg 152

Schmidt A (1961) Zytotaxonomische Untersuchungen an europäischen Viola-Arten der Sektion Nomimium. Oesterr Bot Z 108:20-88

Schmidt A (1992) Violaceae. In: Rechinger KH (ed) Flora iranica, vol 169. Akademische Druck- und Verlagssantalt, Graz

Schöfer G (1954) Untersuchungen über die Polymorphie einheimischer Veilchen. Planta 43:537-565

Sokal RR, Michener CD (1958) A statistical method for evaluating systematic relationships. Univ Kansas Sci Bull 38:1409-1438

Tiniakou A (1991a) Cytogeographical studies on some species of Viola sect. Viola (Violaceae) from Greece. Willdenowia 20:153-158 
Tiniakou A (1991b) Viola dirphya (Violaceae), a new species from Evvia island, Greece. Candollea 46:119-124

Tiniakou A (1995) Viola oligyrtia Tiniakou. In: Phitos D, Strid A, Snogerup S, Greuter W (eds) The red data book of rare and endangered plants of Greece. World Wide Fund for Nature, Athens, pp 516-517

Valentine DH (1950) The experimental taxonomy of two species of Viola. New Phytol 49:193-212

Valentine DH (1962) Variation and evolution in the genus Viola. Preslia 34:190-206

Valentine DH (1975) Viola L. In: Stace CA (ed) Hybridization and the flora of the British Isles. Academic Press, London, pp 154-163

Valentine DH, Merxmüller H, Schmidt A (1968) Viola L. In: Tutin TG, Heywood VH, Burges NA, Moore DM, Valentine DH,
Walters SM, Webb DA (eds) Flora europaea, vol 2. University Press, Cambridge, pp 270-282

van den Hof K, van den Berg RG, Gravendeel BB (2008) Chalcone synthase gene lineage diversification confirms allopolyploid evolutionary relationships of European rostrate violets. Mol Biol Evol 25:2099-2108

van Loon JC, Oudemans JMH (1982) Viola sieheana. In: Löwe A (ed) IOPB Chromosome number reports LXXV. Taxon 31:342-368

Wendel JF, Weeden NF (1989) Visualization and interpretation of plant isozymes. In: Soltis DE, Soltis PS (eds) Advances in plant sciences series, Isozymes in plant biology, vol 4. Dioscorides Press, Portland, pp 6-45

Yuzepchuk SV (1949) Viola L. In: Shishkin BK (ed) Flora of the USSR, vol 15. Israel Program for Scientific Translations, Jerusalem, pp 263-360 